Assiut University web-site: www.aun.edu.eg

\title{
EVALUATION OF THE IMMUNE RESPONSE OF SOME CHICKEN FARMS TO INFECTIOUS BRONCHITIS VIRUS IN AL-AHSA PROVINCE IN SAUDI ARABIA
}

\author{
MOHAMMED ALI AL-HAMMADI \\ Department of Microbiology and Parasitology, College of Veterinary Medicine, Alhufuf, Al-Ahsa, King Faisal University, \\ Saudi Arabia
}

Received: 21 May 2018; Accepted: 8 July 2018

\begin{abstract}
Infectious bronchitis virus (IBV) still to pose great economic losses among chickens of all ages in many parts in the world. Despite the massive application of IBV vaccines in many countries including Saudi Arabia, several outbreaks are still frequently reported. One of the important challenges that hampered the selection of the right vaccine candidates is the identification of the local circulating strain in a certain area. IBV is recently reported in many chickens flocks in the Eastern region of the Kingdom. The major goals of our study were to evaluate the immune status of some chicken farms in Al-Ahsa to IBV. To achieve this goal, total of (368) serum samplesfrom chicken farms from Al-Ahsa region were collected. Our results showing high seroprevelance of IBV in the non-IBV vaccinated chicken farms suggesting their exposure to the natural IBV infection. Meanwhile, we were able to detect a high IBV antibody titers in vaccinated chicken farms suggesting the used vaccines induced detectable IBV antibodies. This suggesting the circulation of novel IBV strains in these chicken farms. The overall results confirm the circulating of novel IBV strains in chicken farms in Al-Ahsa region. Further studies are needed to do molecular characterization of these IBV strains
\end{abstract}

Key words: Infectious bronchitis virus, ELISA, Al-Ahsa, broiler, baladi chickens

\section{INTRODUCTION}

Infectious bronchitis virus (IBV) is a highly contagious respiratory viral disease of chickens of all ages. The IBV belongs to the family Coronaviridae (Hackney et al., 2003, Mardani et al., 2006). The IBV infection usually causes high economic losses among poultry industry. It is quite possible to become an endemic in the chicken industry in some regions of the world. The virus has wide tissue tropism including the respiratory, digestive, renal, and reproductive systems of the affected birds. It may affect the oviduct and lead to low production and low quality eggs, or may causes severe renal complications and mortality among the affected birds (Ignjatovic et al., 2006). The IBV infected birds usually shed the virus in their body secretions such as respiratory and the gastrointestinal tract secretions. These birds may remain active shedders of the virus for up to several weeks post infection (Jahantigh et al., 2013). Secondary bacterial infections (Escherichia coli (E. Coli) and Mycoplasma gallisepticum) always exaggerates the viral pathogenesis and auscultates the mortality rates among the infected chicken population ( $\mathrm{Ji}$ et al.,

Corresponding author: Dr. MOHAMMED ALI AL-HAMMADI E-mail address: malhammadi@kfu.edu.sa

Present address: Department of Microbiology and Parasitology, College of Veterinary Medicine, Alhufuf, Al-Ahsa, King Faisal University, Saudi Arabia.
2011). The IBV infections continues to be a major problem to poultry industry worldwide. In spite of the availability of several IBV vaccines, the virus continues to cause many outbreaks among the chicken farms in both broiler and layer settings (Dhama et al., 2014).

Efforts to control spreading of the IBV infections through vaccination resulted in some variable outcomes. Many IBV strains and serotypes have been emerged since its discovery more than 80 years ago; meanwhile, the misuse of the IBV vaccines complicates the evolution and emergence of new IBV strains (Mase M, 2008). One possible explanation for the emergence of new IBV strains is the poor proof reading capability of the viral RNA polymerase. This resulted in high mutation rates alongside the viral genome. This leads to the emergence of new IBV strains every once in a while (Dolz et al., 2008, Jackwood et al., 2012). Many IBV vaccines are commercially available including inactivated, live attenuated, recombinant etc. The live attenuated vaccines are the most commonly used in all types of poultry; these provide good immune response however, there is a possibility of revert to virulence. Meanwhile, the inactivated vaccines are usually given to layers and breeders before laying as booster vaccines (Jordan, 2017, van Beurden et al., 2018).

Several IBV variants and genotypes are currently circulating in the Middle East, Asia and North Africa such as Iraq, Egypt, Libya, Iran, and Jordan (Zanaty et al., 2016). Furthermore, many outbreaks have been 
reported in Saudi Arabia especially in the central region of the country (Ababneh et al., 2012, Awad et al., 2014, Selim et al., 2013). However, the through molecular characterization of these IBV strains and variants are not well reported yet. The main goal of the current study was to evaluate the immune status of some chicken farms either IBV vaccinated or nonvaccinated using the commercial ELISA kits.

\section{MATERIALS AND METHODS}

\section{Processing of serum samples}

A total of 368 sera from broilers (184) and layers (184) were collected from seven chicken farms (Table 1). Blood samples were collected randomly prior to each exposure. Specimens were placed for 12 hours at room temperature and centrifuged at 5000 RPM for $10 \mathrm{~min}$. The serum was aspirated by micropipettes. Heat inactivation of sera at $56 \mathrm{C}$ for $30 \mathrm{~min}$ was done in a water bath to inactivate the non-specific inhibitors. The separated sera were and stored at $80^{\circ} \mathrm{C}$ for further testing (Praveen \& Narasimha, 2016, Hemida et al., 2017).

Enzyme-linked immunosorbent assay (ELISA)
Evaluation of the IBV antibody titters from birds was done by using commercial available total antibody ELISA (IDVet Screen Infectious Bronchitis Virus Competition, insert 0913, lot 555). ELISA procedures were done as per the kits instructions with minor modifications. Simply, each sample was tested in triplicate. Specimen-to-positive ratios (S/P ratios) was calculated as the percent inhibition as per the following formula.

$(\mathrm{PI} \%)=\frac{\mathrm{OD}(\mathrm{NC})-\mathrm{OD}(\text { sample })}{\mathrm{OD}(\mathrm{NC})} \times 100$ (NC: Negative Control, OD: optical density).

The optical density of samples presenting a PI\% greater than $40 \%$ were considered positive while the OD of samples between $30-40 \%$ were considered doubtful, However, the OD of samples less than $30 \%$ were considered negative. Individual serum titres were calculated from these $\mathrm{S} / \mathrm{P}$ ratios, evaluated as positive or negative, and expressed as OD $450 \mathrm{~nm}$ values according to the manufacturer's instructions. Allow all reagents to come to room temperature before use.

Table 1: Summary of the collected specimens and their geographical distribution 2014-2016.

\begin{tabular}{|c|c|c|c|c|c|c|c|}
\hline No. & Type & $\begin{array}{c}\begin{array}{c}\text { Collection } \\
\text { age }\end{array} \\
\text { Date } \\
\end{array}$ & $\begin{array}{c}\text { Clinical } \\
\text { signs }\end{array}$ & Type of vaccine & $\begin{array}{l}\text { No. of } \\
\text { serum }\end{array}$ & Organs & $\begin{array}{c}\text { Farm } \\
\text { No. }\end{array}$ \\
\hline 1 & B & $\begin{array}{l}35 \text { days } \\
11 / 2014 \\
\end{array}$ & APN & $\begin{array}{l}\text {-IBV }(\mathrm{H} 120) \& \mathrm{NDV} \text {, at } 0 \text { days } \\
\text {-NDV at } 10 \text { days } \\
\text {-IBV at } 16 \text { days }\end{array}$ & 92 & NA & 1 \\
\hline 2 & B & $\begin{array}{l}38 \text { days } \\
11 / 2014 \\
\end{array}$ & APN & $\begin{array}{l}\text {-IBV (H120) \&ND at } 0 \text { days } \\
\text {-NDV at } 10 \text { days } \\
\text {-IBV at } 16 \text { days }\end{array}$ & 92 & NA & 2 \\
\hline 3 & $\mathrm{~L}$ & 150 days & APN & $\begin{array}{l}\text {-IBV (H120) and ND at } 7 \text { days } \\
\text {-IBDV at } 15 \text { days } \\
\text {-NDV (LaSota strain) \& IBDV } \\
\text { at } 19 \text { days } \\
\text {-NDV (LaSota strain) at } 30 \\
\text { days } \\
\text {-AI and NDV at } 38 \text { days } \\
\text {-IBV (H120) at } 42 \text { days } \\
\text {-Fowlpox at } 52 \text { days } \\
\text { - AI \& NDV at70 days } \\
\text {-IBV (H120) and NDV at } 100 \\
\text { days } \\
\text {-NDV at } 120 \text { days }\end{array}$ & 92 & NA & 6 \\
\hline 4 & $\mathrm{~L}$ & $\begin{array}{c}180-210 \text { days } \\
1 / 2015\end{array}$ & $\overline{\mathrm{RS}}$ & NV & 13 & $\begin{array}{l}\text { Trachea, lung } \\
\text { and kidney }\end{array}$ & 7 \\
\hline 5 & $\mathrm{~L}$ & $\begin{array}{c}210-240 \text { days } \\
1 / 2015 \\
\end{array}$ & $\mathrm{RS}$ & NV & 41 & $\begin{array}{c}\text { Trachea, lung } \\
\text { and kidney }\end{array}$ & 5 \\
\hline 6 & $\mathrm{~L}$ & $\begin{array}{c}180-210 \text { days } \\
1 / 2015\end{array}$ & $\overline{\mathrm{RS}}$ & NV & 24 & $\begin{array}{l}\text { Trachea, lung } \\
\text { and kidney }\end{array}$ & 3 \\
\hline 7 & $\mathrm{~L}$ & $\begin{array}{c}270-300 \text { days } \\
2 / 2015\end{array}$ & APN & NV & 14 & $\begin{array}{l}\text { Trachea, lung } \\
\text { and kidney }\end{array}$ & 6 \\
\hline & & & Total & & 368 & 276 & 6 \\
\hline
\end{tabular}

$\mathrm{B}=$ broilers, $\mathrm{L}=$ layers, $\mathrm{APN}=$ apparently normal, $\mathrm{RS}=$ respiratory signs, $\mathrm{IBV}=$ infectious bronchitis virus, $\mathrm{AI}=$ avian influenza, $\mathrm{IBDV}=$ infectious bursal diseases virus, $\mathrm{NDV}=$ newcastle disease virus, $\mathrm{VTC}=$ veterinary training centre, $\mathrm{NV}=$ non vaccinated (did not receive any vaccine for viral diseases). 


\section{RESULTS}

Seroprevalence of IBV in some chicken farms in Al-Hasa

A total of 368 chicken serum samples were tested for the presence of IBV antibodies. Specimens were collected from chicken farms on six regions in $\mathrm{Al}-$ Hasa. Our results are showing that 23/92 (25\%) nonvaccinated chicken sera and 257/276 (93.12\%) (Figure. 5), the vaccinated sera were positive for IBV antibodies (Figure. 6). However, seven samples out of 13 tested from non-vaccinated chicken in Farm No.7 were positive $(53,85 \%)$. Our results are showing that $8 / 41(19.51 \%)$ in farm No.5 and test $6 / 24(25 \%)$ in Farm No.3 sera were positive. However, two samples from chickens in Veterinary Training Centre was IBV antibodies positive out of 14 tested samples (14.29\%) non-vaccinated. In contrast, the antibody IBV ELISA reported much higher 90/92 $(93,83 \%)$ in farm No.1 and same in farm No.2 result was 86/92 (93.48\%) chicken vaccinated. We test 81/92 (88.04\%) chicken vaccinated were positive from the Veterinary Training Centre (Table 2).

Table 2: Summary of the seroprevalence of IBV in some chicken farms in Al-Hasa.

\begin{tabular}{|c|c|c|c|c|c|c|c|c|c|}
\hline \multirow{2}{*}{ No. } & \multirow{2}{*}{$\begin{array}{l}\text { Type of } \\
\text { chicken }\end{array}$} & \multirow{2}{*}{$\begin{array}{c}\text { Collection } \\
\text { of age }\end{array}$} & \multirow{2}{*}{ Type of vaccine } & \multirow{2}{*}{$\begin{array}{l}\text { No. of } \\
\text { serum }\end{array}$} & \multicolumn{2}{|c|}{ No. of } & \multicolumn{2}{|c|}{ No. of } & \multirow{2}{*}{ Farm No. } \\
\hline & & & & & + & $\%$ & - & $\%$ & \\
\hline 1 & B & 35 days & $\begin{array}{l}\text {-IBV (H120) \& NDV, at } 0 \text { days } \\
\text {-NDV at } 10 \text { days } \\
\text {-IBV at } 16 \text { days }\end{array}$ & 92 & 90 & $97.83 \%$ & 2 & $2.17 \%$ & 1 \\
\hline 2 & B & 38 days & $\begin{array}{l}\text {-IBV (H120) \&ND at } 0 \text { days } \\
\text {-NDV at } 10 \text { days } \\
\text {-IBV at } 16 \text { days }\end{array}$ & 92 & 86 & $93.48 \%$ & 6 & $6.52 \%$ & 2 \\
\hline 3 & $\mathrm{~L}$ & 150 days & $\begin{array}{l}\text {-IBV (H120) and ND at } 7 \text { days } \\
\text {-IBDV at } 15 \text { days } \\
\text {-NDV (LaSota strain) \& IBDV at } \\
19 \text { days } \\
\text {-NDV (LaSota strain) at } 30 \text { days } \\
\text {-AI and NDV at } 38 \text { days } \\
\text {-IBV (H120) at } 42 \text { days } \\
\text {-Fowlpox at } 52 \text { days } \\
\text { - AI \& NDV at70 days } \\
\text {-IBV (H120) and NDV at } 100 \\
\text { days } \\
\text {-NDV at } 120 \text { days }\end{array}$ & 92 & 81 & $88.04 \%$ & 11 & $11.96 \%$ & 6 \\
\hline 4 & $\mathrm{~L}$ & $\begin{array}{c}\text { 180-210 } \\
\text { days }\end{array}$ & NV & 13 & 7 & $53.85 \%$ & 6 & $46.15 \%$ & 7 \\
\hline 5 & $\mathrm{~L}$ & $\begin{array}{c}210-240 \\
\text { days }\end{array}$ & NV & 41 & 8 & $19.51 \%$ & 33 & $80.49 \%$ & 5 \\
\hline 6 & $\mathrm{~L}$ & $\begin{array}{c}\text { 180-210 } \\
\text { days }\end{array}$ & NV & 24 & 6 & $25 \%$ & 18 & $75 \%$ & 3 \\
\hline 7 & $\mathrm{~L}$ & $\begin{array}{c}\text { 270-300 } \\
\text { days }\end{array}$ & NV & 14 & 2 & $14.29 \%$ & 12 & $85.71 \%$ & 6 \\
\hline & & & Total & 368 & 280 & $76.09 \%$ & 88 & $23.91 \%$ & 6 \\
\hline
\end{tabular}

$\mathrm{B}=$ broilers, $\mathrm{L}=$ layers, $\mathrm{APN}=$ apparently normal, $\mathrm{RS}=$ respiratory signs, $\mathrm{IBV}=$ infectious bronchitis virus, $\mathrm{AI}=$ avian influenza, IBDV= infectious bursal diseases virus, NDV= Newcastle disease virus, $\mathrm{VTC}=$ veterinary training centre, $\mathrm{NV}=$ non vaccinated (did not receive any vaccine for viral diseases). 


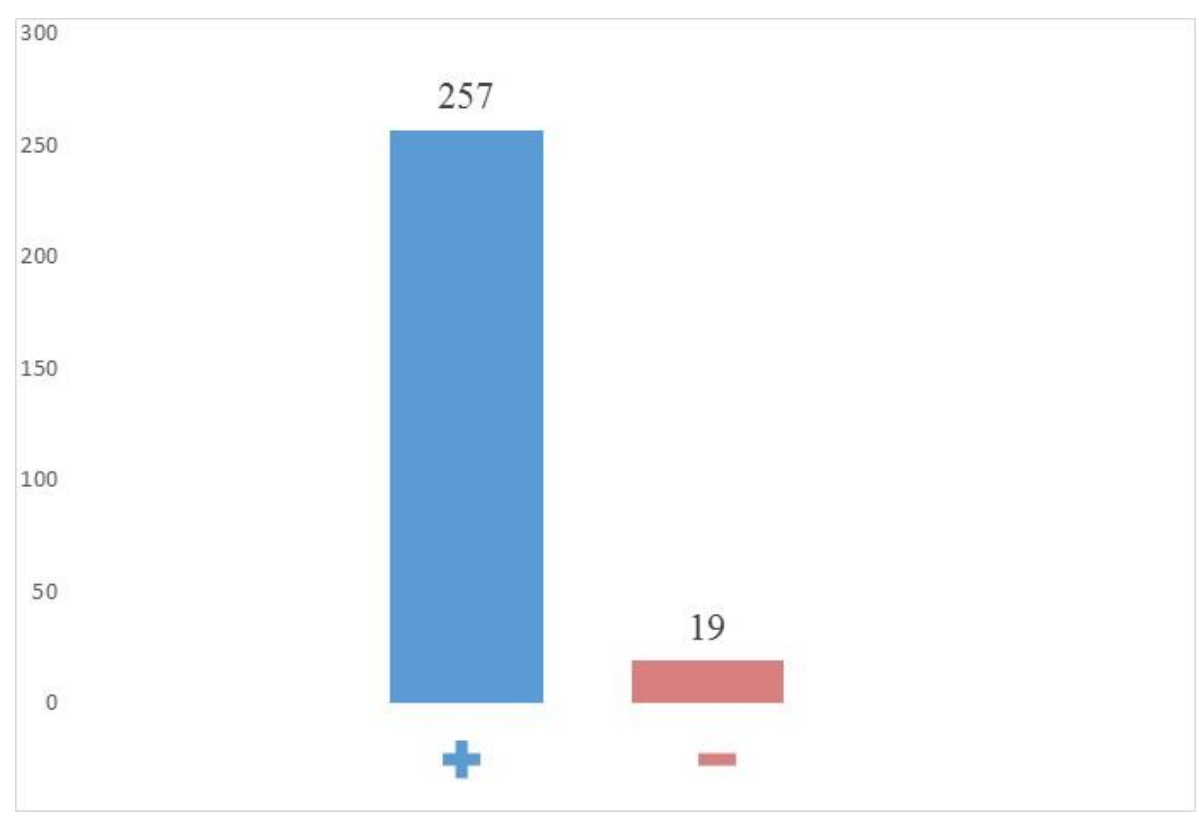

Figure 1: ELISA results of some vaccinated chicken farms in Al-Hasa.

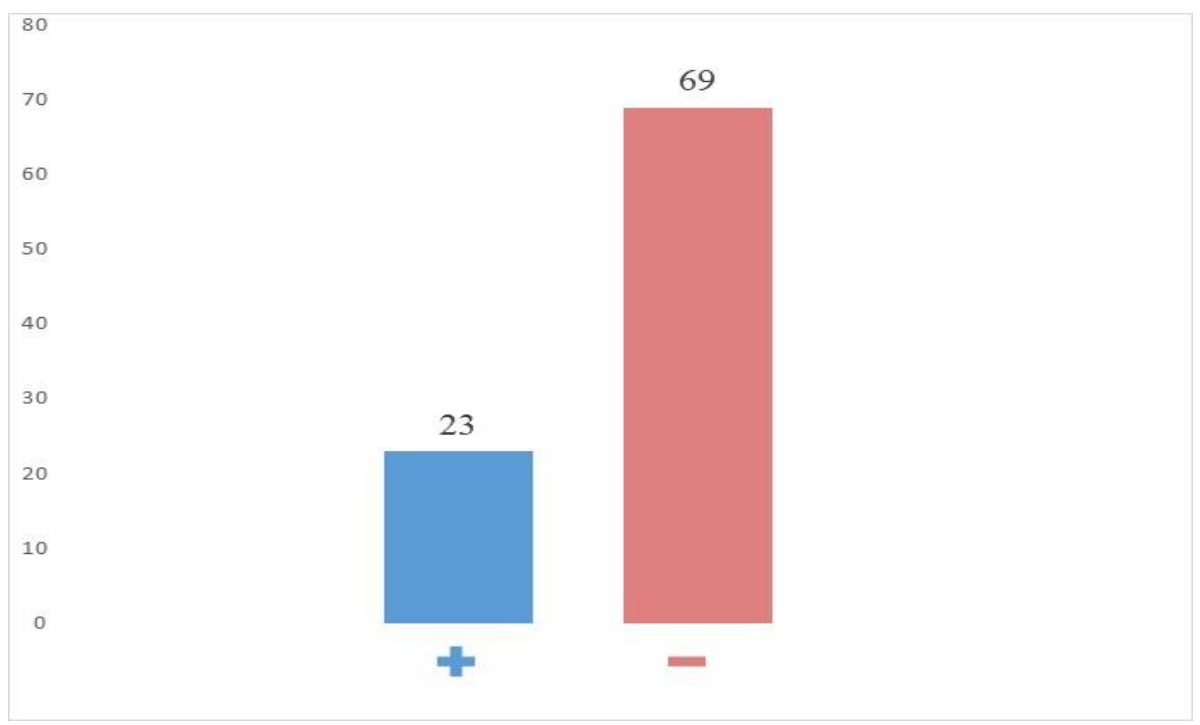

Figure 2: ELISA results of some non-vaccinated chicken farms in Al-Hasa.

\section{DISCUSSION}

Infectious bronchitis virus (IBV) is one of the major viral threats of poultry industry worldwide. There are large number of IBV genotypes identified in many parts around the globe (Khataby et al., 2016, Fellahi et al., 2016). IBV is one of the family Coronaviridae. The IBV viral genome is believed to mutate at a high frequency due to the poor proof reading capabilities of its viral RNA polymerases. Both mutations and recombinations provides ample genetic diversity among the IBV population throughout the world (Jackwood et al., 1992, Najafi et al., 2015, Xu et al., 2016a). Although IBV vaccination is a common practice throughout most poultry farms across the globe, many IBV outbreaks still reported in commercial poultry farms. This resulted in high economic losses to poultry raisers and industry (Mohajer Shojai et al., 2016, Sun \& Liu, 2016). Isolation of many IBV strains and antigenic variants from vaccinated commercial chickens was reported in many cases frequently (Xu et al., 2016b). Recombination occurs among different IBV genes and was reported so frequently especially within the $\mathrm{S}$ gene (Promkuntod et al., 2015, Makhija \& Kumar, 2015). The $\mathrm{N}$ protein plays important roles in the pathogenesis and replication cycle of most coronaviruses. The $\mathrm{N}$ protein has many conserved motifs showing similarity of more than $94 \%$ among different coronaviruses (Sapats et al., 1996). The $\mathrm{N}$ protein is an important diagnostic marker which have been used for diagnostic purposes of many coronaviruses including IBV for long time by the RTPCR technique. Meanwhile, it is most frequently used 
to study the evolution of IBV strains and genotypes (Chang et al., 2016). The live IBV attenuated vaccines are effective tools for controlling IBV when used properly. Improper IBV vaccine distribution within chicken flocks and insufficient vaccine dosage favors the reversion of IBV vaccines to virulence. In some cases using the IBV live vaccine in chickens may increase the susceptibility of birds to be infected with the virus rather than protected from its field infection as planned. (Lim et al., 2015, Reddy et al., 2016, Seger et al., 2016). A serosurveillance study was conducted among some IBV vaccinated and nonvaccinated chickens in some chicken farms across $\mathrm{Al}$ Ahsa region. A total of 368 including 276 IBV vaccinated and 92 non-IBV vaccinated chicken sera were collected. Sera were tested for the presence of IBV antibodies by the commercial available ELISA kits. Our date is showing that 257/276 (93.12\%) (Figure.1) vaccinated chicken were positive while 23/92 (25\%) non-vaccinated sera were positive for IBV (Figure.2). Presence of IBV antibodies in vaccinated chicken sera indicating the IBV vaccines were able to induce antibodies against the IBV antigen. In contrast to the detection of IBV antibodies in non-vaccinated chicken sera indicating that, those birds were exposed to a recent IBV natural infection.

\section{CONCLUSIONS}

Our results confirmed the detection of specific antibodies against IBV in non-vaccinated chickens in Al-Ahsa province. This suggesting those chickens were exposed to an IBV natural infection.

\section{ACKNOWLEDGMENT}

I thank Mr. Musaed Alsultan for his technical assistance with ELISA technique

\section{COMPETING OF INTEREST}

The author declare there is no competing of interest exist

\section{REFERENCES}

Ababneh, M.; Dalab, A.E.; Alsaad, S. and Al-Zghoul, M. (2012): Presence of Infectious Bronchitis Virus Strain CK/CH/LDL/97I in the Middle East. ISRN veterinary science, 2012, 201721.

Awad, F.; Baylis, M. and Ganapathy, K. (2014): Detection of variant infectious bronchitis viruses in broiler flocks in Libya. International Journal of Veterinary Science and Medicine, 2, 78-82.

Chang, C.K.; Lo, S.C.; Wang, Y.S. and Hou, M.H. (2016): Recent insights into the development of therapeutics against coronavirus diseases by targeting N protein. Drug discovery today, 21, 562-572.
Dhama, K.; Singh, S.D.; Barathidasan, R.; Desingu, P.A.; Chakraborty, S.; Tiwari, R. and Kumar, M.A. (2014): Emergence of Avian Infectious Bronchitis Virus and its Variants Need Better Diagnosis, Prevention and Control Strategies: A Global Perspective. Pakistan Journal of Biological Sciences, 17, 751-767.

Dolz, R.; Pujols, J.; Ordonez, G.; Porta, R. and Majo, $N$. (2008): Molecular epidemiology and evolution of avian infectious bronchitis virus in Spain over a fourteen-year period. Virology, 374, 50-59.

Fellahi, S.; Harrak, M.E.; Kuhn, J.H.; Sebbar, G.; Bouaiti, E.A.; Khataby, K.; Fihri, O.F.; Houadfi, M.E. and Ennaji, M.M. (2016): Comparison of SYBR green I real-time RTPCR with conventional agarose gel-based RTPCR for the diagnosis of infectious bronchitis virus infection in chickens in Morocco. BMC Research Notes, 9, 1-9.

Hackney, K.; Cavanagh, D.; Kaiser, P. and Britton, P. (2003): In vitro and in ovo expression of chicken gamma interferon by a defective RNA of avian coronavirus infectious bronchitis virus. Journal of virology, 77, 5694-5702.

Hemida, M.G.; Al-Hammadi, M.A.; Daleb, A.H.S. and Gonsalves, C.R. (2017): Molecular characterization and phylogenetic analyses of virulent infectious bronchitis viruses isolated from chickens in Eastern Saudi Arabia. Virusdisease, 28, 189-199.

Ignjatovic, J.; Gould, G. and Sapats, S. (2006): Isolation of a variant infectious bronchitis virus in Australia that further illustrates diversity among emerging strains. Archives of virology, 151, 1567-1585.

Jackwood, M.W.; Hall, D. and Handel, A. (2012): Molecular evolution and emergence of avian gammacoronaviruses. Infection, genetics and evolution: journal of molecular epidemiology and evolutionary genetics in infectious diseases, 12, 1305-1311.

Jackwood, M.W.; Kwon, H.M. and Hilt, D.A. (1992): Infectious bronchitis virus detection in allantoic fluid using the polymerase chain reaction and a DNA probe. Avian diseases, 36, 403-409.

Jahantigh, M.; Salari, S. and Hedayati, M. (2013): Detection of infectious bronchitis virus serotypes by reverse transcription polymerase chain reaction in broiler chickens. SpringerPlus, 2, 36.

Ji, J.; Xie, J.; Chen, F.; Shu, D.; Zuo, K.; Xue, C.; Qin, J.; Li, H.; Bi, Y.; Ma, J. and Xie, $Q$. (2011): Phylogenetic distribution and predominant genotype of the avian infectious bronchitis virus in China during 2008-2009. Virology journal, 8, 184.

Jordan, B. (2017): Vaccination against infectious bronchitis virus: A continuous challenge. Veterinary microbiology, 206, 137-143. 
Khataby, K.; Kichou, F.; Loutfi, C. and Ennaji, M.M. (2016): Assessment of pathogenicity and tissue distribution of infectious bronchitis virus strains (Italy 02 genotype) isolated from moroccan broiler chickens. BMC Veterinary Research, 12, 1-10.

Lim, T.H.; Youn, H.N.; Yuk, S.S.; Kwon, J.H.; Hong, W.T.; Gwon, G.B.; Lee, J.A.; Lee, J.B.; Lee, S.W. and Song, C.S. (2015): Successful crossprotective efficacy induced by heat-adapted live attenuated nephropathogenic infectious bronchitis virus derived from a natural recombinant strain. Vaccine.

Makhija, A. and Kumar, S. (2015): Analysis of synonymous codon usage in spike protein gene of infectious bronchitis virus. Canadian journal of microbiology, 1-7.

Mardani, K.; Noormohammadi, A.H.; Ignatovic, J. and Browning, G.F. (2006): Typing infectious bronchitis virus strains using reverse transcription-polymerase chain reaction and restriction fragment length polymorphism analysis to compare the $3^{\prime} 7.5 \mathrm{~kb}$ of their genomes. Avian pathology: journal of the W.V.P.A, 35, 63-69.

Mase, M.; Yamaguchi, I.T. and S. Imada T. (2008): Genetic diversity of avian infectious bronchitis viruses in Japan based on analysis of s2 glycoprotein gene. FULL PAPER Avian Pathology, 71(73):287-291.

Mohajer Shojai, T.; Ghalyanchi Langeroudi, A.; Karimi, V.; Barin, A. and Sadri, N. (2016): The effect of Allium sativum (Garlic) extract on infectious bronchitis virus in specific pathogen free embryonic egg. Avicenna Journal of Phytomedicine, 6, 458-267.

Najafi, H.; Langeroudi, A.G.; Hashemzadeh, M.; Karimi, V.; Madadgar, O.; Ghafouri, S.A.; Maghsoudlo, H. and Farahani, R.K. (2015): Molecular characterization of infectious bronchitis viruses isolated from broiler chicken farms in Iran, 2014-2015. Archives of virology.

Praveen, B. and Narasimha, G. (2016): Detection of infectious bronchitis virus by Enzyme Linked Immunosorbent Assay (ELISA) in chickens, p. 295-298.

Promkuntod, N.; Thongmee, S. and Yoidam, S. (2015): Analysis of the S1 gene of the avian infectious bronchitis virus (IBV) reveals changes in the IBV genetic groups circulating in southern Thailand. Research in veterinary science, 100, 299-302.
Reddy, V.R.A.P.; Trus, I.; Desmarets, L.M.B.; Li, Y.; Theuns, S. and Nauwynck, H.J. (2016): Productive replication of nephropathogenic infectious bronchitis virus in peripheral blood monocytic cells, a strategy for viral dissemination and kidney infection in chickens. Veterinary research, 47, 1-19.

Sapats, S.I.; Ashton, F.; Wright P.J. and Ignjatovic, J. (1996): Novel Variation in the N Protein of Avian Infectious Bronchitis Virus. Virology, 226, 412-417.

Seger, W.; GhalyanchiLangeroudi, A.; Karimi, V.; Madadgar, O.; Marandi, M.V. and Hashemzadeh, M. (2016): Genotyping of infectious bronchitis viruses from broiler farms in Iraq during 2014-2015. Archives of virology, 161, 1229-1237.

Selim, K.; Arafa, A.S.; Hussein, H.A. and El-Sanousi, A.A. (2013): Molecular characterization of infectious bronchitis viruses isolated from broiler and layer chicken farms in Egypt during 2012. International Journal of Veterinary Science and Medicine, 1, 102-108.

Sun, J. and Liu, S. (2016): An RT-PCR Assay for Detection of Infectious Bronchitis Coronavirus Serotypes. In: L. Wang (ed.), Animal Coronaviruses. Springer New York, New York, NY.

Van Beurden, S.J.; Berends, A.J.; Kramer-Kuhl, A.; Spekreijse, D.; Chenard, G.; Philipp, H.C.; Mundt, E.; Rottier, P.J.M. and Verheije, M.H. (2018): Recombinant live attenuated avian coronavirus vaccines with deletions in the accessory genes $3 \mathrm{ab}$ and/or $5 \mathrm{ab}$ protect against infectious bronchitis in chickens. Vaccine.

Xu, G.; Liu, X.-y.; Zhao, Y.; Chen, Y.; Zhao, J. and Zhang, G.-z. (2016a): Characterization and analysis of an infectious bronchitis virus strain isolated from southern China in 2013. Virology journal, 13, 40.

Xu, P.W.; Wu, X.; Wang, H.N.; Ma, B.C.; Ding, M.D. and Yang, $X$. (2016b): Assembly and immunogenicity of baculovirus-derived infectious bronchitis virus-like particles carrying membrane, envelope and the recombinant spike proteins. Biotechnology letters, 38, 299-304.

Zanaty, A.; Arafa, A.-S.; Hagag, N. and El-Kady, M. (2016): Genotyping and pathotyping of diversified strains of infectious bronchitis viruses circulating in Egypt. World Journal of Virology, 5, 125-134. 


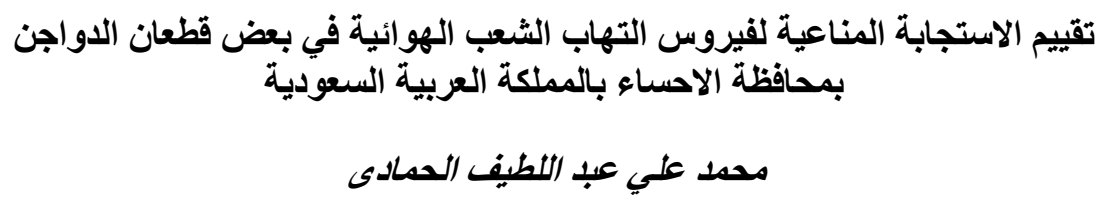

Email: malhammadi@kfu.edu.sa Assiut University web-site: www.aun.edu.eg

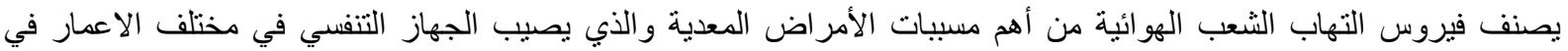

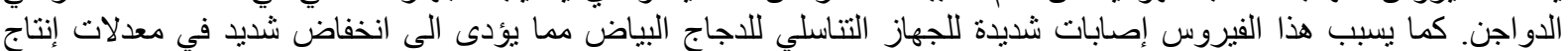

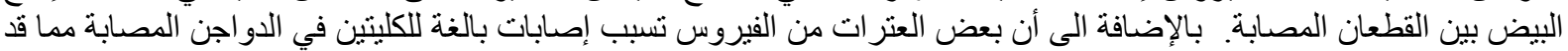

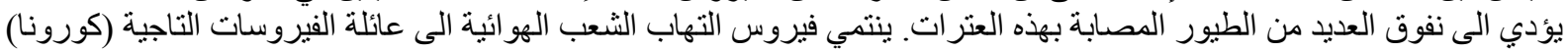

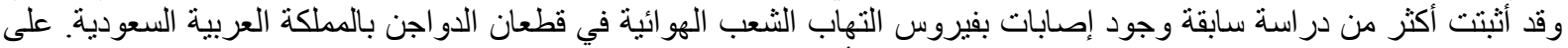

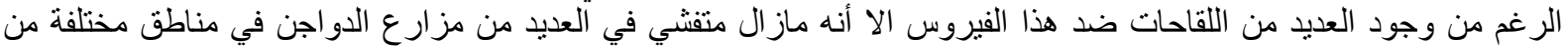

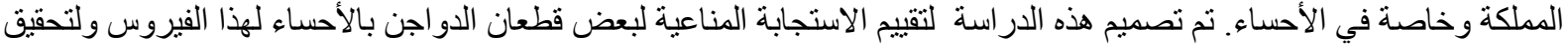

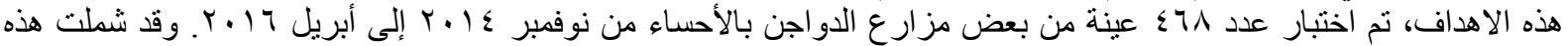

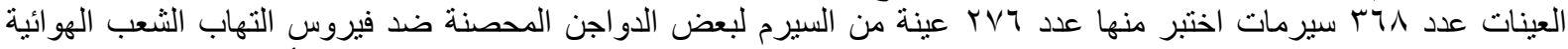

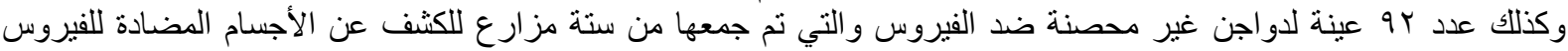

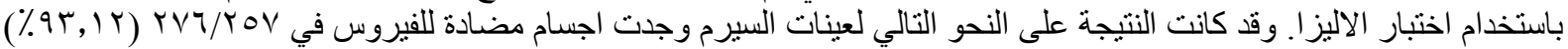

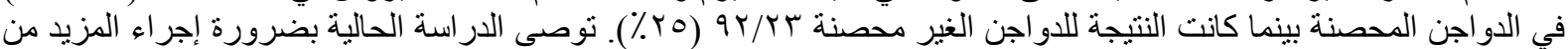

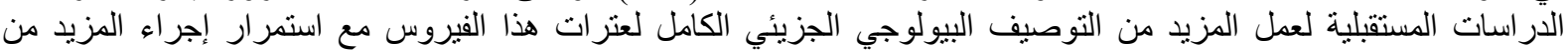

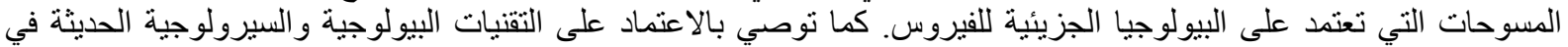

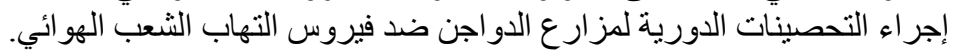

